Jurnal Agro 8(1), 2021

\title{
PARAMETER GENETIK KULTIVAR-KULTIVAR JAGUNG LOKAL PADA CEKAMAN SALINITAS SEDANG
}

\section{GENETIC PARAMETERS OF LOCAL CORN CULTIVARS ON MODERATE SALINITY STRESS}

\author{
Sakka Samudin*, Jeki, Moh. Adnan $\mathrm{Khalik}^{1}$,Ruli Akbar , Muliati, Mustakim \\ Program Studi Agroteknologi Fakultas Pertanian Universitas Tadulako \\ Palu JI. Soekarno-Hatta Km 9, Tondo-Palu, Sulawesi Tengah. 94118 \\ Koresponden: sakka01@yahoo.com
}

Diterima : 24 November 2020 / Disetujui 03 April 2021

\begin{abstract}
Abstrak
Produktivitas jagung di Sulawesi Tengah masih relatif rendah dibanding produksi nasional sehingga perlu ditingkatkan melalui pemuliaan tanaman. Penelitian bertujuan untuk mengkaji parameter genetik tanaman jagung pada cekaman salinitas sedang. Penelitian dilaksanakan pada Juni sampai Agustus 2019, di Green House Fakultas Pertanian, Universitas Tadulako, Palu. Rancangan percobaan yang digunakan adalah Rancangan Acak Lengkap (RAL) terdiri atas 6 perlakuan genotip dan diulang 3 kali serta 5 unit tanaman per perlakuan sehingga terdapat 90 unit percobaan. Parameter genetik yang di analisis adalah koefisiean keragaman genotipik, koefisien keragaman fenotipik, heritabilitas, kemajuan genetik, korelasi, dan analisis sidik lintas. Hasil penelitian menunjukkan bahwa kehijauan daun, bobot tongkol berkelobot, berat tongkol tidak berkelobot, dan berat biji pertongkol memiliki koefisien keragaman genetik tinggi. Kehijauan daun, berat tongkol berkelobot, bobot tongkol tidak berkelobot, panjang tongkol tidak berkelobot, diamater tongkol, berat biji per tongkol dan bobot 100 biji memiliki nilai heritabilitas dan kemajuan genetik tinggi. Seleksi secara tidak langsung dapat dilakukan pada umur panen agar diperoleh hasil jagung lokal yang tinggi pada kondisi tercekam salinitas sedang. Karakter-karakter tersebut dapat dijadikan acuan dalam menyeleksi tanaman jagung dengan cekaman salinitas sedang untuk program pemuliaan jagung.
\end{abstract}

Kata kunci: cekaman salinitas, parameter genetik, kultivar jagung lokal

\begin{abstract}
The productivity of maize in Central Sulawesi is relatively low compared to national production and needs to be improved by plant breeding. The study aimed to examine the genetic parameters of the maize plant traits at moderate salinity stress. The research was conducted from June to August 2019, at the Green House of the Faculty of Agriculture, Tadulako University, Palu. The genetic parameters analyzed were genetic coefficient of variation, phenotypic coefficient of variation, heritability, genetic advance, correlation, and path analysis. The experimental design used a completely randomized design consisting of six genotypic treatments and repeated three times. The results showed that the leaves greenness,
\end{abstract}

ISSN : 2407-7933

Cite this as: Samudin, S., Jeki., Khalik, M.A., Akbar, R., Muliati \& Mustakim. (2021). Parameter genetik kultivar-kultivar jagung local pada cekaman salinitas sedang. Jurnal Agro, 8(1), 55-67. https://doi.org/10.15575/10280 
the weight of the cob with and without husk, and weight of seeds per cob had a high genetic coefficient of variation. Leaf greenness, the weight of the ear with and without husk, ear length without husk, ear diameter, seed weight per ear and yield have a high value of heritability and genetic advance. Indirect selection can be applied through harvest time trait to obtain a high local maize yield in moderate salinity stress condition. These traits can be used as a reference in selecting maize plants with moderate salinity stress for maize breeding programs.

Keyword: genetic parameters, maize landrace, salinity stress

\section{PENDAHULUAN}

Jagung (Zea mays L.) merupakan salah satu jenis tanaman pangan yang memiliki daya adaptasi luas untuk diusahakan (Farooq et al., 2015). Komoditas ini merupakan sumber pangan dan bahan baku untuk pembuatan berbagai macam produk (Ballo et al., 2012). Menurut Qurban et al. (2013) nilai gizi yang dikandung oleh komoditas ini cukup tinggi yaitu $72 \%$ pati, $10 \%$ protein, $4,80 \%$ minyak, $9,50 \%$ serat, 3,0\% gula pasir, dan abu $1,70 \%$.

Pengembangan tanaman jagung di Sulawesi Tengah masih tetap dilakukan oleh petani hingga saat ini, namun produktivitasnya masih rendah. Hal ini dapat dilihat dari produktivitas jagung di Sulawesi Tengah tahun 2019 mencapai 4,349 $\mathrm{t} \mathrm{ha}{ }^{-1}$ (BPS, 2020) sedangkan produktivitas secara nasional telah mencapai 5,42 $\mathrm{t}$ ha ${ }^{-1}$ (BPS, 2019). Rendahnya produktivitas ini disebabkan petani masih menggunakan varietas lokal dan sebagian lagi mengusahakan tanaman di lahan marginal. Varietas lokal merupakan varietas yang telah dibudidayakan dalam kurun waktu yang sangat lama di suatu daerah sehingga mampu beradaptasi dan telah mengalami seleksi alam yang pada akhirnya memiliki keunggulan tertentu (Tucker et al., 2020). Masyarakat memiliki minat yang tinggi mengusahakan tanaman jagung menyebabkan pengusahaannya dilakukan di lahan marginal. Lahan marjinal merupakan suatu hamparan lahan yang telah mengalami degradasi sehingga produktivitasnya rendah. Sebagian besar lahan marjinal berada di daerah kering dan semi kering dimana salinitas tanah juga sering menjadi masalah (Niu et al., 2012). Dengan demikian, perlu dilakukan identifikasi tanaman yang tahan/toleran terhadap kadar garam.

Peningkatan produktivitas tanaman jagung melalui kegiatan pemuliaan tanaman merupakan salah cara untuk memenuhi permintaan dalam negeri yang cukup tinggi. Salah satu kegiatan penting dalam praktek perbaikan sifat suatu tanaman adalah seleksi. Keefektifan suatu seleksi sangat bergantung pada informasi awal tentang parameter genetik (keragaman genetik, daya waris dan hubungan antar sifat) sifat-sifat yang akan diperbaiki (Syukur et al., 2012). Dengan demikian, informasi tersebut sangat diperlukan sebelum perbaikan sifat suatu tanaman dilakukan (Mustakim et al., 2019; Ritonga et al., 2018) pada kondisi cekaman garam.

Keragaman genetik berkaitan dengan terdapatnya perbedaan individu dalam populasi sehingga memudahkan untuk memilihi genotip yang unggul dari genotip tidak unggul dalam proses seleksi. Hasil 
penelitian Hefny (2011) menunjukkan bahwa sifat berat tongkol per tanaman, jumlah baris per tongkol, dan hasil pipilan memiliki koefisien keragaman genetik (KKG) tinggi. Selain itu, diameter tongkol dan berat tongkol memiliki koefisien keragaman genetik tergolong sedang, sedangkan sifat umur berbunga jantan $50 \%$, umur berbunga betina $50 \%$, panjang tongkol dan jumlah biji per tongkol memiliki KKG rendah. Heritabilitas ditujukan untuk mengetahui sampai sejauhmana suatu sifat dapat diturunkan dari tetua kepada turunannya. Selain itu, dapat digunakan untuk menentukan meode seleksi yang sesuai untuk perbaikan sifat (Bello et al., 2012).

Hasil merupakan sifat yang sangat kompleks dan pewarisannya melibatkan banyak gen (poligen) dan hasil memiliki hubungan dengan komponenkomponennya. Analisis korelasi sederhana akan memperlihatkan hubungan antara sifat hasil dan sifat-sifat lainnya. Jika terdapat hubungan antara dua sifat maka seleksi dapat dilakukan secara tidak langsung untuk meningkatkan sifat yang diinginkan.

Beberapa peneliti telah melakukan penelitian tentang korelasi sederhana antara hasil dengan sifat-sifat tanaman jagung. Nzuve et al. (2014) menemukan bahwa sifat letak tongkol dan tinggi tanaman memiliki hubungan bersifat positif dan berbeda terhadap hasil tanaman jagung. Menurut Belay (2018), korelasi antar dua sifat (hasil dengan satu komponen hasil) saja kurang memberikan gambaran yang akurat tentang korelasi antar sifat sebab dalam korelasi antar sifat tidak hanya melibatkan dua sifat melainkan melibatkan beberapa sifat yang saling berinteraksi. Sekaitan dengan masalah tersebut, maka Patil et al. (2016) mengusulkan untuk menggunakan analisis lain yang dapat memperlihatkan hubungan lebih dari dua sifat dan saling berinteraksi.

Sidik lintas dapat memperlihatkan hubungan yang kompleks antara suatu sifat terhadap hasil. Selain itu, akan memperlihatkan sifat-sifat yang memberikan kontribusi terbesar terhadap hasil melalui sifat yang lain. Penelitian tentang parameter genetik tanaman jagung pada kondisi tercekam salinitas sedang belum banyak dilakukan.

Artikel ini bertujuan untuk mengkaji parameter genetik (koefisien variasi genetik, heritabilitas dan hubungan antar sifat) beberapa kultivar jagung lokal pada cekaman salinitas sedang.

\section{BAHAN DAN METODE}

Penelitian dilaksanakan pada Bulan Juni sampai dengan Bulan Agustus 2019, bertempat di Green House Fakultas Pertanian, Universitas Tadulako, Palu. Alat yang di gunakan meliputi: timbangan digital, timbangan analitik, jangka sorong, cangkul, sekop, mistar, selang, ember, gelas ukur $1000 \mathrm{ml}$, parang, oven, gelas tabung, pinset, alat ukur kehijauan daun (SPAD-502 reading, Minolta Camera Co., Osaka, Japan), alat pengukur luas daun (portabel area meter Model LI 3000C), kamera dan alat tulis. Bahan yang digunakan adalah tanah, label, polibag, pupuk N, P, K, dan lakban. Penelitian ini menggunakan Rancangan Acak Lengkap karena kondisi lingkungan dan materi percobaan homogen kecuali perlakuan (Steel \& Torrie, 1980) terdiri atas 6 perlakuan genotip, yaitu Kultivar Gento, Lanca, Lei, Pulut Lokal, merah sigi dan Jagung Biasa. Setiap perlakuan diulangi 
sebanyak 3 kali dan setiap perlakuan terdiri atas 5 unit tanaman sehingga terdapat 90 unit percobaan.

Tanah yang digunakan merupakan jenis tanah alluvial dengan C-organik 2,42\% (sedang), $\mathrm{N}$ total $0,22 \%$ (sedang), $\mathrm{K} 0,45$ (me $100 \mathrm{~g} \mathrm{~g}^{-1}$ ), P205 (olsen) 16,32 ppm (tergolong tinggi) dan pH 7,2 (netral). Tanah dimasukkan ke dalam polybag yang berukuran $60 \times 40 \mathrm{~cm}$, masing-masing dengan berat $20 \mathrm{~kg}$ sebanyak 75 polybag. Benih direndam selama $1 \times 24$ jam, dipilih yang baik dan ditanam dua biji per polibag. Pemupukan Urea dengan dosis $330 \mathrm{~kg} \mathrm{ha}^{-1}$ (setara 3,3 $\mathrm{g}^{\text {polibag }}{ }^{-1}$ ), diberikan pada umur 10 hari setelah tanam sebanyak $1 \mathrm{~g}$, 30 hari setelah tanam 1,3 $\mathrm{g}$ polibag $^{-1}$ dan

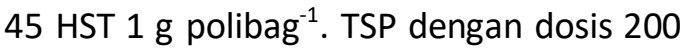
$\mathrm{kg} \mathrm{ha}^{-1}$ (setara $2 \mathrm{~g}$ polibag $^{-1}$ ) dan dosis $\mathrm{KCl}$ $100 \mathrm{~kg} \mathrm{ha}^{-1}$ (setara $1 \mathrm{~g}$ polibag ${ }^{-1}$ ) diberikan bersamaan waktu tanam. Larutan $\mathrm{NaCl}$ tergolong sedang dengan dosis $2500 \mathrm{ppm}$ (EC $5 \mathrm{ds} \mathrm{m}^{-1}$ ) (Chaudhary et al., 2017) diberikan pada umur 31 HST. Pemberian air dengan volume $2000 \mathrm{ml}$ setiap polibag dilakukan dua kali sehari untuk setiap polibag. Panen dilakukan apabila tanaman memenuhi kriteria panen seperti tongkol jagung sudah kering, biji mengkilap dan jika ditekan dengan kuku tangan tidak menimbulkan bekas tekanan atau tidak patah (Gustian et al., 2019).

Parameter pengamatan meliputi: Diameter Batang $(\mathrm{cm})$, Tinggi Tanaman $(\mathrm{cm})$, kehijauan daun (\%), umur berbunga jantan (hari), umur berbunga betina (hari), Letak tongkol $(\mathrm{cm})$, Umur Panen (hari), Berat Tongkol Berkelobot (g), Berat Tongkol Tidak Berkelobot (g), Panjang Tongkol Berkelobot $(\mathrm{cm})$, Panjang Tongkol Tidak Berkelobot $(\mathrm{cm})$, Diameter Tongkol (cm), Jumlah biji pertongkol (biji), Berat Biji Pertongkol (g), hasil biji (g).
Koefisien keragaman genotipik dan koefisien keragaman fenotipik dihitung menggunakan formulasi (Burton \& DeVane, 1953), heritabilitas dengan nilai $0-<30 \%$ tergolong rendah, $30-60 \%$ tergolong sedang dan tinggi $>60$ dan kemajuan genetik harapan dihitung menggunakan formulasi (Johnson et al., 1955; Mustakim et al., 2019; Syukur et al., 2012), koefisien korelasi dihitung menggunakan formulasi (Al-Jibour et al., 1958) dan analisis sidik lintas dihitung menggunakan formulasi (Dewey \& Lu, 1959).

\section{HASIL DAN PEMBAHASAN}

Hasil analisis keragaman menunjukkan bahwa perlakuan genotip memberikan pengaruh nyata terhadap semua peubah yang diamati. Pengaruh yang nyata ini menunjukkan bahwa semua kultivar yang diamati memiliki respon genetik yang berbeda untuk tumbuh dan berkembang bila ditanam pada kondisi cekaman salin/garam sedang (Niji et al., 2018).

\section{Koefisien Keragaman Genotipik dan Fenotipik}

Nilai duga KKG dan KKF dari beberapa sifat yang diamati pada tanaman jagung kultivar lokal disajikan pada Tabel 1. Nilai KKG dan KKF yang diamati pada semua sifat memiliki nilai hampir sama, kondisi ini terjadi menurut (Patil et al., 2016) akibat pengaruh genetik dan lingkungan dalam penampilan sifat tanaman. Hasil penelitian ini sejalan dengan hasil penelitian sebelumnya yang telah dilakukan Niji et al. (2018) sedangkan hasil penelitian Arunkumar et al. (2018) menunjukkan bahwa KKF lebih besar dibanding KKG. Praveenkumar et al. (2014) menguraikan bahwa KKG atau KKF tergolong rendah jika bernilai < 10\%, tergolong sedang jika 
bernilai $10-20 \%$ dan tergolong tinggi jika bernilai $>20 \%$. Berdasarkan kriteria ini maka tinggi tanaman, umur keluar bunga jantan, umur keluar bunga betina, letak tongkol, umur panen, dan panjang tongkol berkelobot memiliki KKG dan KKF yang tergolong rendah. Sifat diameter batang, panjang tongkol tanpa kelobot, diameter tongkol dan berat 100 biji tergolong sedang, sedangkan sifat kehijauan daun, berat tongkol berkelobot, berat tongkol tidak berkelobot, dan berat biji pertongkol memiliki KKG dan KKF yang tinggi (Tabel 1).

Tabel 1. Nilai koefisien keragaman genotipik dan fenotipik beberapa sifat kultivar jagung lokal

\begin{tabular}{|c|c|c|}
\hline Sifat yang diamati & KKG & KKF \\
\hline Diameter batang & 10,02 & 10,51 \\
\hline Tinggi tanaman & 4,92 & 4,95 \\
\hline Kehijauan daun & 20,64 & 20,79 \\
\hline $\begin{array}{l}\text { Umur berbunga } \\
\text { jantan }\end{array}$ & 8,55 & 9,10 \\
\hline $\begin{array}{l}\text { Umur berbunga } \\
\text { betina }\end{array}$ & 9,26 & 9,44 \\
\hline Letak tongkol & 6,11 & 6,14 \\
\hline Umur panen & 6,45 & 6,63 \\
\hline $\begin{array}{l}\text { Berat tongkol } \\
\text { berkelobot }\end{array}$ & 29,93 & 29,94 \\
\hline $\begin{array}{l}\text { Berat tongkol tidak } \\
\text { berkelobot }\end{array}$ & 32,45 & 32,51 \\
\hline $\begin{array}{l}\text { Panjang tongkol } \\
\text { berkelobot }\end{array}$ & 4,91 & 5,44 \\
\hline $\begin{array}{l}\text { Panjang tongkol } \\
\text { tidak berkelobot }\end{array}$ & 12,78 & 13,05 \\
\hline Diameter tongkol & 14,76 & 15,70 \\
\hline $\begin{array}{l}\text { Jumlah baris } \\
\text { pertongkol }\end{array}$ & 6,50 & 6,61 \\
\hline $\begin{array}{l}\text { Berat Biji } \\
\text { pertongkol }\end{array}$ & 24,87 & 24,92 \\
\hline Hasil biji & 11,16 & 11,23 \\
\hline
\end{tabular}

Sifat-sifat yang memiliki nilai KKG tinggi menunjukkan bahwa penampilanya secara dominan dipengaruhi oleh faktor genetik sehingga perbaikan sifatnya melalui proses seleksi akan efektif. Berat 1000 butir, tinggi tongkol, umur berbunga jantan, interval umur berbunga betina, diameter tongkol, jumlah biji perbaris, panjang tongkol, tinggi tanaman dan luas daun merupakan sifat-sifat dengan KKG tergolong sedang (Tadesse et al., 2018). Selanjutnya ditegaskan bahwa beberapa sifat seperti jumlah baris pertongkol, umur berbunga betina 50\%, umur berbunga jantan 50\%, umur panen, panjang daun, dan lebar daun memiliki KKG rendah. Hasil penelitian Arunkumar et al. (2018) menunjukkan bahwa umur berbunga, umur berbunga betina, panjang tongkol, lingkar tongkol, jumlah baris pertongkol, dan berat 100 butir memiliki KKG yang rendah.

Menurut Tadesse et al. (2018) sifat-sifat yang memiliki nilai KKG rendah dikaitkan dengan plastisitas fenotipik dan munculnya alel yang bersitfat positif dan negatif dalam genotipe jagung sehingga menyebabkan keragaman genetik rendah pada kondisi kadar garam sedang. Dalam kaitan dengan seleksi, sifat yang memiliki nilai KKG rendah tidak dapat diperbaiki sehingga untuk meningkatkan KKG maka genotip/kultivar harus disilangkan.

\section{Heritabilitas dan Kemajuan Genetik}

Heritabilitas merupakan ukuran varians fenotipik yang disebabkan oleh penyebab genetik dan memberikan informasi tentang bagaimana suatu sifat diturunkan ke generasi lebih lanjut. Selain itu, heritabilitas digunakan untuk menentukan metode seleksi yang sesuai dalam perbaikan suatu sifat (Bello et al., 2012). Nilai heritabilitas dan kemajuan genetik sifat-sifat kultivar jagung lokal yang diamati 
dalam penelitian disajikan pada Tabel 2 . Nilai heritabilitas berkisar antara 0,81 hingga 0,99. Nilai heritabilitas dari semua sifat yang diamati dalam penelitian ini tergolong tinggi (Tabel 2).

Tabel 2. Nilai heritabilitas dan kemajuan genetik beberapa sifat kultivar jagung lokal

\begin{tabular}{lcc}
\hline $\begin{array}{l}\text { Sifat yang } \\
\text { diamati }\end{array}$ & $\begin{array}{c}\text { Heritabili } \\
\text { tas }\end{array}$ & $\begin{array}{c}\text { Kemajuan } \\
\text { Genetik } \\
\text { (\%) }\end{array}$ \\
\hline $\begin{array}{l}\text { Diameter Batang } \\
\text { Tinggi Tanaman }\end{array}$ & 0,91 & 19,69 \\
$\begin{array}{l}\text { Kehijauan Daun } \\
\text { Umur berbunga }\end{array}$ & 0,99 & 16,40 \\
jantan & 0,88 & 16,54 \\
$\begin{array}{l}\text { Umur berbunga } \\
\text { betina }\end{array}$ & 0,96 & 18,73 \\
$\begin{array}{l}\text { Letak Tongkol } \\
\text { Umur Panen }\end{array}$ & 0,99 & 12,51 \\
$\begin{array}{l}\text { Berat Tongkol } \\
\text { berkelobot }\end{array}$ & 0,95 & 12,92 \\
$\begin{array}{l}\text { Berat Tongkol } \\
\text { Tidak berkelobot } \\
\text { Panjang tongkol } \\
\text { berkelobot }\end{array}$ & 0,99 & 61,63 \\
$\begin{array}{l}\text { Panjang tongkol } \\
\text { tidak berkelobot }\end{array}$ & 0,81 & 66,70 \\
$\begin{array}{l}\text { Diameter } \\
\text { Tongkol }\end{array}$ & 0,96 & 25,79 \\
$\begin{array}{l}\text { Jumlah baris } \\
\text { pertongkol }\end{array}$ & 0,97 & 28,58 \\
$\begin{array}{l}\text { Berat Biji } \\
\text { pertongkol } \\
\text { Hasil biji }\end{array}$ & 0,99 & 51,11 \\
\hline & 0,99 & 22,85 \\
\hline
\end{tabular}

Hasil penelitian ini sejalan dengan penelitian yang diperoleh Matin et al. (2017) untuk sifat umur berbunga jantan, umur berbunga betina, tinggi tanaman, letak tongkol, umur panen, panjang tongkol, diameter tongkol, berat 1000 biji, dan hasil.

Hasil penelitian Sinay \& Tanrobak (2020) pada tanaman jagung memperoleh nilai heritabilitas tinggi untuk sifat jumlah biji pertongkol, panjang tongkol, jumlah baris pertongkol, tinggi tanaman, jumlah daun, panjang daun, lebar daun, dan berat tongkol saat panen. Ayodeji \& Comfort (2019) menemukan hasil penelitian yang berbeda untuk sifat hasil, jumlah biji perbaris, jumlah tongkol yang dapat dipasarkan, panjang tongkol, diameter tongkol, letak tongkol, tinggi tanaman, dan umur berbunga betina memiliki heritabilitas tergolong cukup tinggi sedangkan umur keluar bunga jantan tergolong rendah.

Sifat-sifat yang memiliki heritabilitas tinggi menunjukkan bahwa sifat tersebut sangat mudah untuk diperbaiki dengan tingkat kemajuan yang cepat (Ballo et al., 2012). Namun demikian, nilai heritabilitas sendiri belum memberikan informasi genetik yang memadai tanpa dibarengi dengan kemajuan genetik (Patil et al., 2016).

Menurut Belay et al. (2018) kemajuan genetik tergolong rendah jika bernilai $<10 \%$, sedang $10-20 \%$ dan tinggi $>20 \%$. Berdasarkan hal tersebut, maka panjang tongkol berkelobot, jumlah baris pertongkol dan berat biji pertongkol termasuk sifat dengan kemajuan genetik rendah. Diameter batang, tinggi tanaman, umur berbunga jantan, umur berbunga betina, letak tongkol, dan umur panen merupakan sifat dengan kemajuan genetik sedang. Kehijauan daun, berat tongkol berkelobot, berat tongkol tidak berkelobot, panjang tongkol tidak berkelobot, diameter tongkol, berat biji pertongkol dan hasil adalah sifat-sifat yang mempunyai kemajuan genetik tergolong tinggi.

Nilai heritabilitas dan kemajuan genetik yang tergolong sedang hingga tinggi memberikan petunjuk adanya peran gengen aditif sehingga pewarisan suatu sifat 
dari induknya kepada keturunan lebih lanjut akan lebih cepat terjadi (Matin et al., 2017). Sebaliknya, sifat yang memiliki nilai heritabilitas dan kemajuan genetik yang rendah menunjukkan bahwa lingkungan berpengaruh terhadap pewarisan sifat dari tetua kepada turunannya sehingga perbaikan sifat tidak akan efektif. Hasil penelitian sebelumnya yang telah dilakukan oleh Ballo et al. (2012); Patil et al. (2016) memperoleh nilai heritabilitas dan kemajuan genetik tergolong tinggi untuk sifat seperti letak tongkol, jumlah biji pertongkol, tinggi tanaman, berat tongkol, jumlah biji perbaris, dan berat 100 butir.

\section{Korelasi antar Sifat}

Hasil merupakan sifat yang sangat kompleks sehingga perbaikan hasil harus memperhatikan komponen hasil yang lain yang berkorelasi dengan hasil. Korelasi genotipik dan fenotipik antara hasil dengan komponen hasil pada kultivar jagung lokal disajikan pada Tabel 3. Nilai koefisien korelasi genotipik lebih tinggi dibanding koefisien korelasi fenotipik, berarti korelasi ini lebih disebabkan oleh pengaruh genetik dibanding pengaruh lingkungan dan kondisi ini lebih disukai oleh pemulia dalam perbaikan sifat. Hasil penelitian menunjukkan bahwa umur berbunga betina, waktu keluar bunga jantan, waktu panen dan jumlah baris pertongkol mempunyai korelasi positif dan nyata terhadap hasil. Selain itu, berat tongkol berkelobot dan berat biji pertongkol berkorelasi genotipik negatif dan nyata terhadap hasil.

Hasil penelitian ini dapat sejalan maupun tidak sejalan dengan hasil penelitian terdahulu. Atnafu \& Rao (2014) menemukan korelasi genotipik negatif dan nyata antara hasil dengan waktu keluar bunga betina $50 \%$, waktu kelaur bunga jantan 50\% dan umur berbunga 50\%. Hasil penelitian Patil et al. (2016) menunjukkan bahwa umur berbunga betina, umur berbunga jantan, dan letak tongkol berkorelasi genotipik positif tetapi tidak nyata terhadap hasil jagung. Sebaliknya, tinggi tanaman, jumlah tongkol, jumlah biji perbaris, dan bobot 100 biji berkorelasi genotipik positif dan nyata terhadap hasil. Matin et al. (2017) menemukan korelasi positif dan nyata antara hasil tongkol berkelobot dengan tongkol tidak berkelobot, tinggi tanaman, letak tongkol, panjang tongkol berkelobot, panjang tongkol tidak berkelobot, diamater tongkol, jumlah biji perbaris, dan jumlah baris pertongkol. Matin et al. (2017) menemukan korelasi genotipik tinggi antara diameter tongkol dan tinggi letak tongkol terhadap hasil jagung. Reddy \& Jabeen (2016) menemukan hasil berkorelasi genotipik positif nyata dengan berat 100 butir, diameter tongkol, jumlah biji perbaris, tinggi tanaman, panjang tongkol dan letak tongkol.

Korelasi genotipik yang positif dan nyata terhadap hasil menunjukkan bahwa sifatsifat tersebut memiliki kontribusi yang besar terhadap hasil. Dengan demikian, sifat lain akan bertambah jika terjadi penambahan pada sifat yang saling berhubungan. Korelasi genotipik negatif dan nyata terhadap hasil menunjukkan bahwa sifat-sifat tersebut memiliki kontribusi menurunkan hasil tanaman jagung.

\section{Analisis Sidik Lintas}

Korelasi antar dua sifat hanya melibatkan dua sifat yaitu antara hasil dengan salah satu komponen hasil. Dalam kenyataannya, korelasi antar hasil 
Tabel 3. Korelasi genotipik beberapa sifat tanaman jagung lokal

\begin{tabular}{|c|c|c|c|c|c|c|c|c|c|c|c|c|c|c|c|}
\hline Sifat & DB & $T T$ & HD & MM & MR & TLT & UP & BTDK & BTTK & PTDK & PTTK & DT & JBT & BBT & Hsl \\
\hline \multicolumn{16}{|l|}{ DB } \\
\hline TT & 0,37 & & & & & & & & & & & & & & \\
\hline HD & $-0,69 *$ & $-0,25$ & & & & & & & & & & & & & \\
\hline MM & 0,34 & $-0,35$ & $-0,16$ & & & & & & & & & & & & \\
\hline MR & $0,92 *$ & $0,71^{*}$ & $-0,45$ & 0,09 & & & & & & & & & & & \\
\hline TLT & $-0,13$ & $-0,50^{*}$ & 0,48 & $-0,30$ & $-0,18$ & & & & & & & & & & \\
\hline UP & $0,88^{*}$ & $0,50 *$ & $-0,32$ & $0,50 *$ & $0,91^{*}$ & $-0,24$ & & & & & & & & & \\
\hline BTDK & $-0,61^{*}$ & $-0,22$ & 0,09 & $-0,61^{*}$ & $-0,62^{*}$ & 0,15 & $-0,82^{*}$ & & & & & & & & \\
\hline BTTK & 0,42 & $-0,06$ & $-0,70^{*}$ & $0,75^{*}$ & 0,14 & $-0,70^{*}$ & 0,34 & $-0,32$ & & & & & & & \\
\hline PTDK & 0,38 & $0,78^{*}$ & $0,53^{*}$ & 0,25 & $0,51^{*}$ & $-0,98 *$ & $0,56^{*}$ & $-0,36$ & $-0,34$ & & & & & & \\
\hline PTTK & $-0,32$ & $-0,11$ & 0,41 & $0,67^{*}$ & $-0,24$ & $-0,44$ & 0,15 & $-0,34$ & 0,34 & 0,34 & & & & & \\
\hline DT & $0,56^{*}$ & 0,47 & $-0,71^{*}$ & $0,57^{*}$ & 0,48 & $-0,92^{*}$ & $0,57^{*}$ & $-0,42$ & 0,06 & $1,00^{*}$ & 0,34 & & & & \\
\hline JBT & 0,30 & 0,07 & $-0,05$ & $0,90 *$ & 0,24 & $-0,57^{*}$ & $0,61^{*}$ & $-0,67^{*}$ & $0,67 *$ & $0,61^{*}$ & $0,84^{*}$ & $0,69 *$ & & & \\
\hline BBT & $-0,04$ & 0,17 & $-0,69 *$ & $-0,07$ & $-0,15$ & $-0,73^{*}$ & $-0,28$ & 0,36 & $0,60^{*}$ & $0,57^{*}$ & $-0,09$ & $0,61^{*}$ & $-0,03$ & & \\
\hline HsI & $0,54^{*}$ & 0,15 & 0,21 & $0,59 *$ & $0,60 *$ & 0,12 & $0,84^{*}$ & $-0,81^{*}$ & 0,06 & 0,14 & 0,39 & 0,15 & $0,64^{*}$ & $-0,70^{*}$ & \\
\hline
\end{tabular}




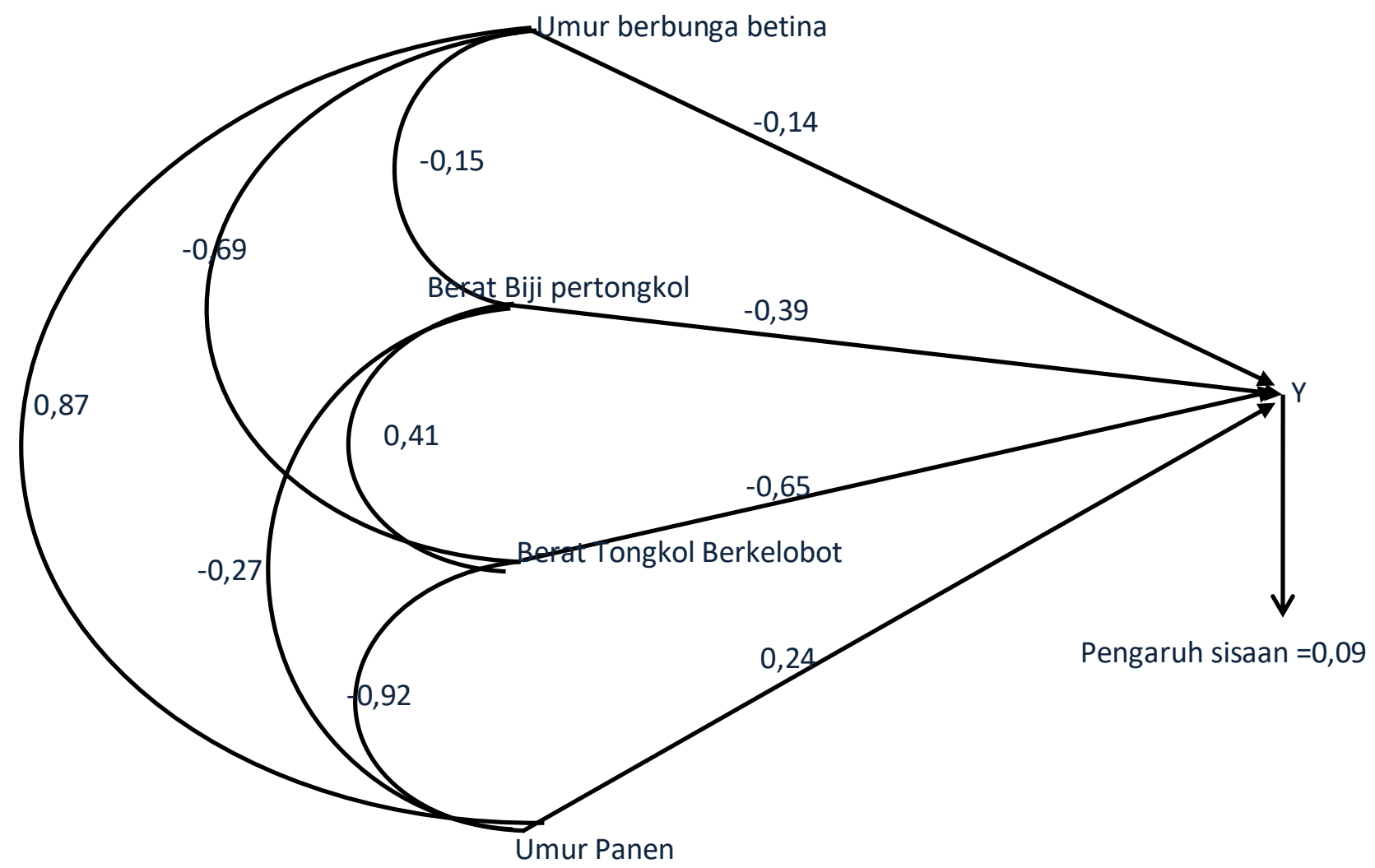

Gambar 1. Efek langsung beberapa sifat terhadap hasil kultivar jagung lokal 
melibatkan beberapa sifat yang dapat terjadi secara terpisah atau bersamaan, sehingga korelasi sederhana yang melibatkan dua sifat masih meragukan untuk digunakan dalam proses seleksi. Menurut Belay et al. (2018) untuk mengatasi keraguan tersebut dapat digunakan analisis sidaik lintas. Analisis sidik lintas telah luas digunakan untuk memberikan informasi lebih lanjut tentang keterkaitan sifat di antara berbagai karakter dan pengaruhnya terhadap hasil tanaman. Analisis sidik lintas memungkin pembagian koefisien korelasi menjadi efek langsung dan tidak langsung dari berbagai sifat terhadap variabel dependen, dan juga membantu dalam menilai hubungan sebabakibat serta seleksi yang efektif (Ballo et al., 2012). Hasil analisis sidik lintas antara beberapa sifat dengan hasil setelah uji t (14 variabel) dan trimming (7 variabel) disajikan pada Gambar 1.

Sifat berat tongkol berkelobot memiliki efek langsung dan korelasi negatif yang tinggi terhadap hasil, diikuti berat biji pertongkol, umur panen dan umur berbunga betina. Tingginya efek langsung berat tongkol berkelobot terhadap hasil selain ditentukan oleh efek langsungnya juga ditentukan oleh efek tidak langsung melalui berat biji pertongkol, umur berbunga betina dan umur panen. Berat tongkol berkelobot merupakan sifat yang memiliki kontribusi terbesar terhadap hasil $(49,23 \%)$, diikuti berat biji pertongkol $(27,30 \%)$, umur panen $(19,71 \%)$ dan umur berbunga betina $(3,16 \%)$.

Beberapa peneliti telah melaporkan hasil penelitian sebelumnya seperti diameter tongkol (Matin et al., 2017), panjang tongkol, tinggi tanaman, umur berbunga (Patil et al., 2016), letak tongkol, umur berbunga betina dan berat 1000 biji
(Shukla, 2017) memiliki efek langsung yang tinggi terhadap hasil jagung. Reddy \& Jabeen (2016), menemukan umur berbunga betina memiliki efek langsung yang tinggi diikuti jumlah biji perbaris, berat 100 biji dan diameter tongkol terhadap hasi.I Hasil temuan ini sama dengan (Sudika et al., 2015). Untuk melakukan seleksi secara tidak langsung dengan memanfaatkan analisis sidik lintas, dianjurkan sifat yang dipilih adalah sifat yang memiliki efek langsung yang tinggi terhadap hasil dan memiliki efek total (korelasi sederhana antara suatu sifat dengan hasil) yang tinggi dan nyata (Shukla, 2017).

Hasil penelitian menunjukkan bahwa sifat berat tongkol berkelobot yang memiliki efek langsung dan korelasi yang tinggi terhadap hasil tidak dapat digunakan dalam melakukan seleksi tidak langsung untuk meningkatkan hasil jagung sebab efeknya bersifat negatif. Demikian pula, berat biji pertongkol tidak dapat digunakan sebagai kriteria seleksi tidak langsung untuk meningkatkan hasil jagung. Hal ini disebabkan peningkatan sifat-sifat tersebut akan menurunkan hasil jagung lokal. Oleh karena itu, umur panen dapat digunakan sebagai kriteria meningkatkan hasil jagung melalui seleksi secara tidak langsung pada kondisi cekaman salinitas sedang karena memiliki efek langsung positif cukup tinggi dan korelasi genetik tinggi.

\section{SIMPULAN}

Dari uraian diatas dapat diambil kesimpulan sebagai berikut:

1. Kehijauan daun, bobot tongkol berkelobot, berat tongkol tidak berkelobot, dan berat biji pertongkol merupakan beberapa sifat yang 
memiliki nilai koefisien keragaman genotipik tinggi pada kondisi tercekam salinitas sedang

2. Keefektifan seleksi meningkat apabila dilakukan pada sifat kehijauan daun, bobot tongkol berkelobot, berat tongkol tidak berkelobot, panjang tongkol tidak berkelobot, diamater tongkol, berat biji pertongkol dan berat 100 butir karena memiliki nilai heritabilitas dan kemajuan genetik tinggi pada kondisi salinitas sedang.

3. Peningkatan hasil jagung lokal pada kondisi tercekam salinitas sedang dapat dilakukan melalui seleksi secara tidak langsung pada sifat umur panen.

\section{UCAPAN TERIMA KASIH}

Terima kasih diucapkan kepada semua pihak yang telah membantu mempelancar pelaksanaan penelitian ini. Diucapkan terima kasih pula kepada Fakultas Pertanian Universitas Tadulako yang telah membiayai penelitian ini.

\section{DAFTAR PUSTAKA}

Al-Jibouri, H.A., Muller, P.A, \& Robinson, H.F. (1958). Genetic and environmental variances and covariances in an upland cotton cross of inter specific origin. Agronomy J, 50, 633-636.

Arunkumar, B., Gangapp, E., Ramesh, S., Savithramma, D.L., Nagaraju, N, \& Lokesha, R. (2018). Genetic potential, variability, heritability and genetic advance of grain yield and its component traits in maize (Zea mays L.) inbreds. International Journal of Chemical Studies, 6(6), 2015-2018.

Atnafu, B. \& Rao, T.N. (2014). Estimates of heritability, genetic advance and correlation study for yield and it's attributes in maize (Zea mays L.). Journal of Plant Sciences, 2(1), 1-4

Ayodeji, A., \& Comfort, A.A. (2019). Genetic variability, heritability and genetic advance in shrunken-2 supersweet corn (Zea mays L. saccharata) populations. Journal of Plant Breeding and Crop Science, 11(4), 100-105. https://doi.org/10.5897/jpbcs2018.07 99

Badan Pusat Statistik, (2019). Indonesia Dalam Angka. Badan Pusat Statistik, Jakarta.

Badan Pusat Statistik, (2020). Sulawesi Tengah Dalam Angka. Badan Pusat Statistik Provinsi Sulawesi Tengah.

Chaudhary, W.B., Ali, M.A., Bajwa, K.S., Iqbal, A., Khan, M.A.U., Shahid, A.A., Aslam, M. (2017). Correlation analysis of maize genotypes under saline stress and its impact on morphological characteristics. Life Science Journal, 14(7), 93-101. https://doi.org/10.7537/marslsj14071 7.15

Ballo, M., Nio, S.A., Mantiri, F.R., \& Pandiangan, D. (2012). Respons Morfologis Beberapa Varietas Padi (Oryza sativa L.) terhadap Kekeringan pada Fase Perkecambahan. Jurnal Bios Logos, 2(2). https://doi.org/10.35799/jbl.2.2.2012 .1045

Belay, N. (2018). Genetic variability, heritability, correlation and path coefficient analysis for grain yield and yield component in maize (Zea mays L.) hybrids. Advances in Crop Science and Technology, 6(5), 1-9.

Burton, G.W., \& DeVane, E.H. (1953). Estimating Heritability in Tall Fescue (Festuca Arundinacea) from Replicated Clonal Material 1. 
Agronomy Journal, 45(10), 478-481. https://doi.org/10.2134/agronj1953.0 $0021962004500100005 x$

Gustian, M., Rustikawati, \& Herison, W.C. (2019). Response of 25 Hybrid Maize Against Salinity Stress and Their Performance in Coastal Area. Agritropica: Journal of agricultural science, 2(2), 56-70. https://doi.org/10.31186/Jagritropica .2.2.56-70

Dewey, D.R., \& Lu, K.H. (1959). A Correlation and Path-Coefficient Analysis of Components of Crested Wheatgrass Seed Production 1. Agronomy Journal, 51(9), 515-518. https://doi.org/10.2134/agronj1959.0 $0021962005100090002 x$

Farooq, M., Hussain, M., Wakeel, A., \& Siddique, K.H.M. (2015). Salt stress in maize: effects, resistance mechanisms, and management. A review. Agronomy for Sustainable Development, 35,(2), 461-481. https://doi.org/10.1007/s13593-0150287-0

Hefny, M. (2011). Genetic parameters and path analysis of yield and its components in corn inbred lines (Zea mays L.) at different sowing dates. Asian Journal of Crop Science, 3(3), 106-117. https://doi.org/10.3923/ajcs.2011.10 6.117

Johnson, H.W., Robinson, H. F, \& Comstock, R. E. (1955). Estimates of genetic and environmental variability in soybeans. Agronomy J, 47, 314-318.

Matin, M.Q.I., Uddin, M.D.S., Rohman, M.D.M., Amiruzzaman, M., Azad, A.K, \& Banik, B.R. (2017). Genetic variability and path analysis studies in hybrid maize (Zea mays L.). American Journal of Plant Sciences, 8, 3101-
3109.

https://doi:

10.4236/ajps.2017.812209

Mustakim, Samudin, S., \& Maemunah. (2019). Genetic Diversity, Heritability And Correlation Between Local Cultivars Of Upland Rice. Agroland: The Agricultural Sciences Journal, 6(1), 20-26.

Niji, M.S., Ravikesavan, R., Ganesan, K.N., \& Chitdeshwari, T. (2018). Genetic variability, heritability and character association studies in sweet corn (Zea mays L. saccharata). Electronic Journal of Plant Breeding, 9(3), 10381044. https://doi.org/10.5958/0975928X.2018.00129.1

Nzuve, F., Githiri, S., Mukunya, D.M., \& Gethi, J. (2014). Genetic Variability and Correlation Studies of Grain Yield and Related Agronomic Traits in Maize. Journal of Agricultural Science, 6(9), 166-176. http://erepository.uonbi.ac.ke/handl e/11295/73805.

Patil, S.M., Kumar, K., Jakhar, D.S., Rai, A., Borle, U.M., \& Singh, P. (2016). Studies on Variability, Heritability, Genetic advance and Correlation in Maize (Zea mays L.). International Journal of Agriculture, Environment and Biotechnology, 9(6), 1103. https://doi.org/10.5958/2230732x.2016.00139.x

Praveenkumar, B., Sridevi, O, \& Salimath, P.M. (2014). Study of genetic variability in s1 maize (zea mays I.) Inbred lines under stress condition. Plant Archives, 14(2), 679-685.

Qurban, A., Muhammad, A., Muhammad, H.N.T., \& Shahzad, M.A.B. (2013). Genetic studies of morphophysiological traits of maize (Zea mays L.) seedling. African Journal of 
Agricultural Research, 8(28), 36683678.

https://doi.org/10.5897/ajar2013.757 6

Reddy, V.R. \& Jabeen, F. (2016). Narrow sense heritability, correlation and path analysis in maize (Zea mays L.). Sabrao J Breed Genet, 48, 120-126.

Ritonga, A.W., Chozin, M.A., Syukur, M., Maharijaya, A., \& Sobir, S. (2018). Short Communication: Genetic variability, heritability, correlation, and path analysis in tomato (Solanum lycopersicum) under shading condition. Biodiversitas, Journal of Biological Diversity, 19(4), 15271531.

Shukla, N. (2017). Genetic variation and association study for grain yield in germplasm accessions of maize (Zea mays L.). Indian Journal of Agricultural Research, 51(2), 120-127. https://doi.org/10.18805/ijare.v0iOF. 7628

Sinay, H., \& Tanrobak, J. (2020). Heritability Analysis of Local Corn Cultivars from Kisar Island Southwest Maluku After Induced with Colchicine. Biosaintifika: Journal of Biology \& Biology Education, 12(1), 119-124. https://doi.org/10.15294/biosaintifik a.v12i1.19847

Sudika, I., Wayan, N.B., Arifin, N.S, \& Andy, S. (2015). Estimation of genetics variance components from composite and hybrid maize (Zea mays L.) hybridization. International Journal of Plant Research 5(5), 107-112. https://doi: 10.5923/j.plant.20150505.0 3

Steel, R. G. D., \& Torrie, J. H. (1960). Principles and procedures of statistics. McGraw-Hill Book Company, Inc., New York, Toronto,
London. 1960 pp.xvi + 481 pp.

Syukur, M., Sujiprihati, S., Yunianti, R., \& Nida, K. (2012). Pendugaan Komponen Ragam, Heritabilitas dan Korelasi untuk Menentukan Kriteria Seleksi Cabai (Capsicum annuum L.) Populasi F5. Jurnal Hortikultura Indonesia, 1(2), 74. https://doi.org/10.29244/jhi.1.2.7480

Tadesse, J., Leta, T., Techale, B., \& Lemi, B. (2018). Genetic variability, heritability and genetic advance of maize (Zea mays L.) inbred lines for yield and yield related traits in southwestern Ethiopia. Journal of Plant Breeding and Crop Science, 10(10), 281-289. https://doi.org/10.5897/jpbcs2018.07 42

Tucker, S.L., Dohleman, F.G., Grapov, D., Flagel, L., Yang, S., Wegener, K.M., Kosola, K., Swarup, S., Rapp, R.A., Bedair, M., Halls, S.C., Glenn, K.C., Hall, M.A., Allen, E., \& Rice, E.A. (2020). Evaluating maize phenotypic variance, heritability, and yield relationships at multiple biological scales across agronomically relevant environments. Plant, Cell \& Environment, 43(4), 880-902. https://doi.org/10.1111/pce.13681 